\title{
Mensagem das religiões e espiritualidades aos povos
}

\author{
Fórum Alternativo Mundial da Água
}

Brasília, 22 de março de 2018

\section{AS ÁGUAS CONVOCAM}

Nós, membros de diferentes tradições religiosas e espiritualidades, nos reunimos no Fórum Alternativo Mundial da Água realizado em Brasília/Brasil, nos dias 17 a 22 de março de 2018, para afirmar as Águas como Dom de Deus, Direito de todas as criaturas e Bem comum. Sentimo-nos convocados e convocadas pelas águas para ouvir seus clamores que brotam das graves situações socioambientais causadas pela ganância do ser humano que o leva a usar irresponsavelmente os recursos naturais. Armamos a nossa Tenda Inter-religiosa no FAMA 2018 e, em diálogo com movimentos populares, povos originários, ONGs e tantas outras organizações da sociedade civil, a partir dos nossos credos e em sintonia com toda a criação, afirmamos que a água é um direito, e não mercadoria. As nossas tradições religiosas e espirituais têm uma relação profunda com as águas. Elas nos vinculam com a realidade do Transcendente através de nossas liturgias, de nossos ritos de iniciação, de purificação, de louvação e de agradecimento. Elas expressam características do criador, como Vida - sem água não há vida; Gratuidade - a água não é mercadoria; Liberdade - a água não pode ser privatizada; Comunhão - a água é um bem comum. Por isso, as águas têm para nós uma dimensão sagrada em sua origem e em sua finalidade: a vida que do divino procede e se realiza na existência de todas as criaturas. Como elemento vital, as águas entrelaçam o natural e o espiritual, o sagrado e o profano, a mística e a política, a individualidade e a comunidade. Ela conecta os diferentes contextos locais e globais onde o curso da vida percorre na direção da fraternidade entre os povos, que partilham de um elemento vital a todos: a água.

\section{AS ÁGUAS CLAMAM}

As águas têm um movimento próprio, como um ser vivo que precisa seguir livremente o seu curso para gerar e sustentar outras vidas. Mas elas sofrem hoje os efeitos de um sistema movido por ambições de lucro e as consequências das mudanças climáticas, que alteram os seus ciclos e ameaçam a vida no planeta. Por isso, as águas clamam por justiça socioambiental que supere os projetos de privatização, mercantilização e a depredação da natureza. 
Revista Brasileira de Diálogo Ecumênico e Inter-religioso

O FAMA 2018 acontece no Brasil, onde as restrições do acesso à água expressam as escandalosas desigualdades sociais: o país que guarda $12 \%$ das reservas de água do mundo convive com mais de $80 \%$ do seu povo sem acesso à água de qualidade. Cerca de 1/3 da população mundial está na mesma situação e mais da metade da humanidade não usufrui de saneamento básico seguro. Há tentativas de respostas meramente técnicas a esses problemas; outros apresentam soluções com interesses de obter lucros diante das graves situações em que se encontram os nossos mares, aquíferos, rios, córregos e nascentes. Tais propostas afetam diretamente os nossos povos, sobretudo indígenas, quilombolas, ribeirinhos e habitantes das periferias das cidades, aumentando ainda mais as desigualdades sociais e os sofrimentos, principalmente de mulheres e crianças.

Nesse contexto, ouvimos o clamor das águas por justiça e por direitos. A água é dom de Deus e não propriedade privada para ser comprada e vendida. Por isso, o acesso à água de forma gratuita e livre é um direito de todos e todas. Para nossas tradições religiosas e espiritualidades, essa é uma forma privilegiada de viver a nossa fé no criador das águas de todo o planeta. Como nos ensinam os povos indígenas: se as águas nos foram dadas de graça, por que pagar por elas?

\section{AS ÁGUAS NOS ENVIAM}

Unimo-nos às vozes que denunciam toda ação que atenta contra o valor sagrado da água, transformando-a em mercadoria desprovida de vida e de direitos. Como religiosos e religiosas alçamos nossa voz profética, denunciando os projetos de morte e defendendo propostas éticas e políticas que superem a desordem provocada pelas injustiças sociais e ambientais. Para isso propomos como ações concretas:

- Formação espiritual e teológica, técnica e política, que permita promover comunidades como sujeitos de relações justas para com a natureza, especificamente a água e seus territórios;

- Ações de articulação, aliança e incidência que vincule agendas locais com os processos regionais e globais de desenvolvimento sustentável, justiça climática e combate às desigualdades socioculturais;

- Estratégias comuns de comunicação que favoreçam intercâmbios de experiências e de saberes, ações de denúncia pública e divulgação das alternativas que envolvem os povos nos processos de justiça para com a água e toda a criação.

Convocamos todos os credos e as organizações baseadas na fé para que se integrem às vozes proféticas e às ações transformadoras na sociedade brasileira, latino-americana e de todos os continentes, vinculando mística e política no fortalecimento de projetos locais e globais que defendem as nossas águas como direito e não mercadoria, por serem elas dom de Deus e bem comum.

\section{Tenda Inter-religiosa do Fórum Alternativo Mundial da Água}

Caminhos de Diálogo, Curitiba, ano 6, n. 8, p. 101-102, jan./jun. 2018

102 ISSN 2595-8208 